\title{
Studies on Phytoconstituents and Biological Potential of Stem of Moringa oleifera
}

\author{
JYOTI PUNIA* and RAJVIR SINGH \\ Department of Chemistry and Biochemistry, College of Basic Sciences and Humanities, \\ Chaudhary Charan Singh Haryana Agricultural University, Hisar-125004, Haryana, India. \\ *Corresponding author E-mail: jyotipunia11@gmail.com \\ http://dx.doi.org/10.13005/ojc/340352 \\ (Received: March 03, 2018; Accepted: May 10, 2018)

\begin{abstract}
Stem of Moringa oleifera were collected, shadow dried and chopped into small pieces. These were then extracted using methanol by refluxing method and the crude extract obtained was divided into two parts. One part was subjected to column chromatography which afforded a total of four compounds, namely, Cholest-5-en-3-ol(I), Stigmasterol(II), Gamma-sitosterol(III) and Tricosanoic acid(IV). All these compounds were first time reported from stem of Moringa. The other part of the crude extract was fractionated using different polarity solvents viz, hexane, benzene, chloroform, ethyl acetate, acetone and water. These fractions and methanol extract were then evaluated for antifungal activity by poisoned food technique against two phytopathogenic fungi. All the fractions were found to be more active against Rhizoctonia solani and Fusarium oxysporum.
\end{abstract}

Keyword: Phytoconstituents, Biological Potential, Moringa oleifera.

\section{INTRODUCTION}

Moringa oleifera commonly known as ben oil tree or drumstick tree is a small sized tree native to India, Africa and Arabia'. It is well known for its medicinal value as its all parts are used in the medicine. Roots and fruits are antiparalytic ${ }^{2}$. The roots are also laxative, expectorant, diuretic and good for inflammations, throat, bronchitis, piles and cures stomatitis, urinary discharges and obstimate asthma ${ }^{3}$. The root juice of Moringa oleifera when mixed with milk helps to cure lower back pain as it contains analgesics called moringine and moringinine ${ }^{4}$. Its roots are also prescribed for the treatment of snakebites and scorpion stings. Its leaves are antihelmentic, aphrodisiac and cure hallucinations, dry tumors, hiccough and asthma ${ }^{5}$. Moringa flowers are a rich source of potassium and calcium. They are also used in the folk remedies for tumors. They also act as hypocholesterolemic and antiarthritic agents and helps to cure urinary problems and cold 6 . Immature pods are good source of palmitic acid, linoleic acid, linolenic acid and oleic acids. So they can be used in the diet of an obese person ${ }^{7}$. The medicinal value of this plant was long been used in folk remedies and was attributed to the presence of

This is an Open Access article licensed under a Creative Commons Attribution-Non Commercial-Share Alike 4.0 International License (https://creativecommons.org/licenses/by-nc-sa/4.0/), which permits unrestricted Non Commercial use, distribution and reproduction in any medium, provided the original work is properly cited. 
various bioactive compounds in its different parts. But the stem of Moringa oleifera remained unexecuted by the scientific community for its bioactive components as well as for its bioevaluation. So, the relevance and innovation of this study lies in the isolation, characterization and biological potential of Moringa oleifera stem.

\section{EXPERIMENTAL}

Sodium hydroxide, sodium silicate, Neseller's reagent, 2,4-dinitrophenol(DNP), ammonium molybdate and ammonium vandate were purchased from CDH, Daryaganj, New Delhi. All the solvents used in this study were of analytical grade and purchased from $\mathrm{CDH}$ or SD Fine Chem Limited, Mumbai, India. The adsorbents used for chromatography were silica gel (60-120 mesh) and silica gel $G$ and were obtained from Himedia Laboratories Pvt. Ltd., Nashik, Mumbai. $1 \mathrm{H}$ NMR spectra of the isolated compounds were recorded on Sophisticated multinuclear FT NMR Spectrophotometer model Avance-II (Bruker $400 \mathrm{MHz}$ ). $\mathrm{CDCl}_{3}$ and DMSO were used as solvents. Chemical shifts were recorded in $\delta(\mathrm{ppm})$ using Tetramethyl silane (TMS) as an internal standard. LC-MS were recorded with a Waters Micromass Q-ToF Micro Mass spectrometer. It is equipped with electronspray ionization (ESI) and atmospheric pressure chemical ionization (APcl) source having mass range of $4000 \mathrm{amu}$ in quadruple and 20000 amu in ToF. Melting points were determined with a Ganson Electrical Melting Point apparatus. IR spectra were recorded with a Perkin Elmer Spectrum RX-I FTIR. It has a resolution of $1 \mathrm{~cm}^{-1}$ and scan range of 4000 to $250 \mathrm{~cm}^{-1}$.

\section{MATERIAL AND METHODS}

\section{Plant material}

Stem of Moringa oleifera were collected from the campus of Chaudhary Charan Singh Haryana Agricultural University, Hisar, Haryana, India. These were washed thoroughly with water to remove dust, shadow dried and chopped into small pieces. These were then kept in air tight containers for further use.

\section{Extraction and fractionation}

The shadow dried, chopped pieces of stem of drumstick tree $(2 \mathrm{~kg})$ were extracted with hot methanol by refluxing method for eight hours. The process was repeated thrice and the respective extractives were pooled together. The obtained extractives were evaporated on a rotary evaporator to give a crude extract (176 g). This extract was further divided into two parts. One major part $(100 \mathrm{~g})$ was mixed with silica gel (60-120 mesh size) and used to fill the column. The remaining part $(76 \mathrm{~g})$ was further fractionated with different polarity solvents viz hexane, benzene, chloroform, ethyl acetate, acetone and water. Each obtained fraction was evaporated to give a crude mass and stored in a refrigerator till use. These fractions and methanolic extract were used for determination of antifungal activity (Figure 1).

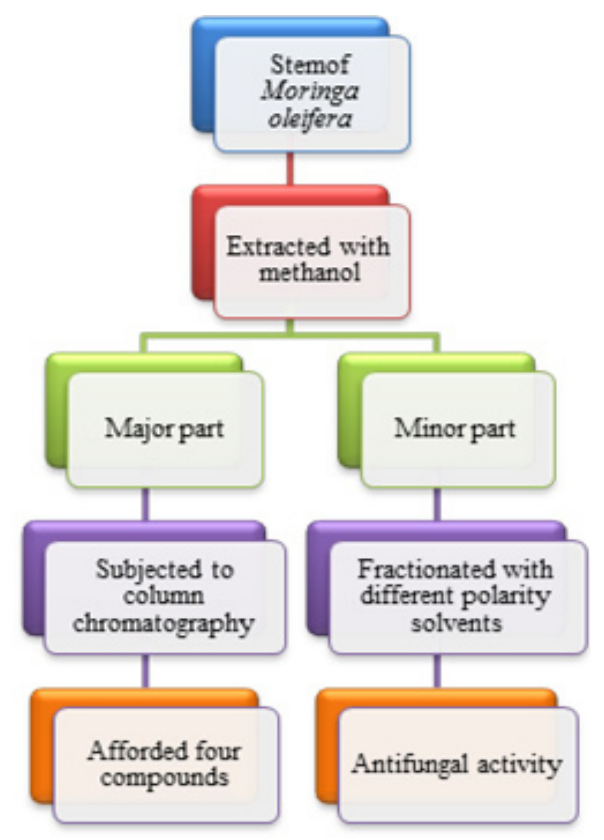

Fig. 1. Extraction, fractionation and isolation scheme of stem of Moringa oleifera

\section{Preliminary phytochemical screening}

The freshly prepared methanolic extract of stem of Moringa oleifera was subjected to qualitative chemical tests using standard methods. This helps in the identification of various classes of bioactive chemical constituents.

\section{Column chromatography}

The methanolic extract of stem of Moringa oleifera which was mixed with silica gel 60-120 mesh size subjected to column chromatography. A glass 
column of $1000 \times 40 \mathrm{~mm}$ size was packed with slurry of silica gel (60-120 mesh size) in hexane. A portion of the methanolic extract of stem was introduced onto the column and eluted with solvents of increasing polarity The elutropic series of solvents used was hexane, benzene, ethyl acetate, methanol and their mixtures. Each eluate obtained was monitored by using Thin Layer Chromatography plates. The column chromatography afforded four compounds labeled as I to IV.

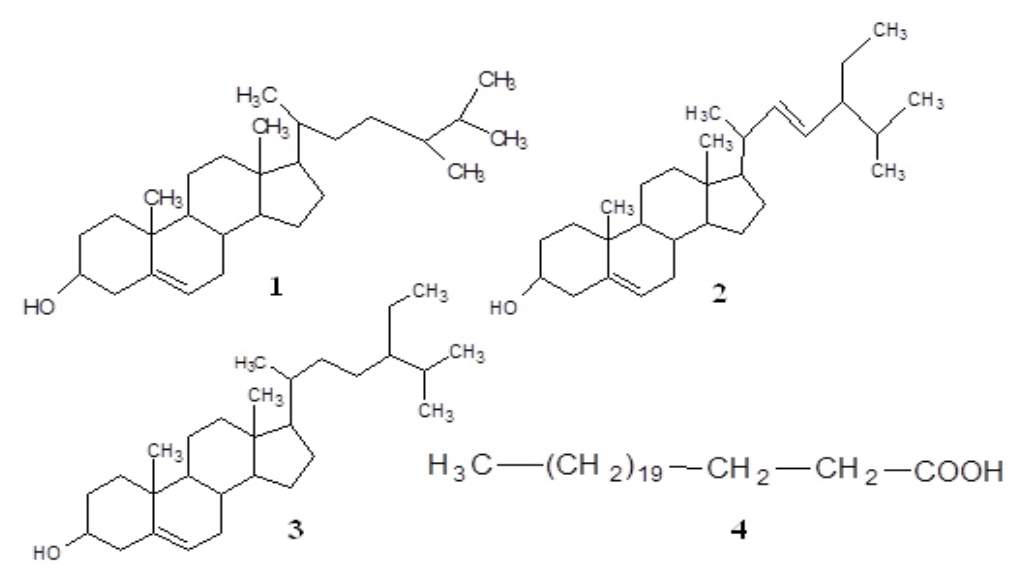

Fig.2. Chemical structures of compounds isolated from stem of Moringa oleifera

Compound I Fractions (1-15) were repeatedly separated by silica gel column chromatography on elution with benzene: hexane (1:9). It was crystallized by using acetone and obtained as white needles (30 mg) having melting point $144-146^{\circ} \mathrm{C}$. Its Rf value was found to be 0.42 in benzene. The molecular formula $\mathrm{C}_{28} \mathrm{H}_{48} \mathrm{O}$ was deduced from its GCMS having molecular mass 400 .

${ }^{1} \mathrm{H} \mathrm{NMR}\left(\delta, \mathrm{CDCl}_{3}\right) \quad 0.88\left(\mathrm{~s}, 3 \mathrm{H}, \mathrm{C}_{18}-\mathrm{CH}_{3}\right)$, $0.90\left(\mathrm{~s}, 3 \mathrm{H}, \mathrm{C}_{26}-\mathrm{CH}_{3}\right), 0.97\left(\mathrm{~s}, 3 \mathrm{H}, \mathrm{C}_{27}-\mathrm{CH}_{3}\right), 1.11$ $\left(\mathrm{s}, 3 \mathrm{H}, \mathrm{C}_{19}-\mathrm{CH}_{3}\right), 1.15\left(\mathrm{~s}, 3 \mathrm{H}, \mathrm{C}_{21}-\mathrm{CH}_{3}\right), 1.18(\mathrm{~s}, 3 \mathrm{H}$, $\left.\mathrm{C}_{28}-\mathrm{CH}_{3}\right), 1.24-2.88\left(\mathrm{~m}, 26 \mathrm{H}, 10 \times-\mathrm{CH}_{2}, 6 \times-\mathrm{CH}_{3}\right), 3.60$ $(\mathrm{m}, \mathrm{J}=4.0 \mathrm{~Hz}, 1 \mathrm{H}, \mathrm{CH}-\mathrm{OH}), 5.34(\mathrm{~m}, \mathrm{~J}=8.0 \mathrm{~Hz}, 1 \mathrm{H}$, $=\mathrm{CH})$.

${ }^{13} \mathrm{CNMR}\left(\delta, \mathrm{CDCl}_{3}\right) 141.80,120.15,71.56$, $55.10,50.15,40.28,38.20,33.40,32.75,28.20$, 28.10, 22.10, 14.10, 13.70 .

\section{IR}

$v_{\mathrm{KBr}}^{\max }\left(\mathrm{cm}^{-1}\right) ; 3419,3322,2955,2927$, 2852, 1462, 1378, 1259, 1055, 801, 759.

LC-MS (m/z, \% intensity) 400 (78), 315.3 (80), 255.2 (52), 213.2 (94), 145.1 (100), 107.1 (82).

Compound II was obtained on elution with benzene: hexane (1:9). Fractions 16-26 were separated by silica gel column chromatography and were pooled together after observing their TLC. The compound was crystallized from benzene $(25 \mathrm{mg})$. The purity of the compound was confirmed by Thin Layer Chromatography. The melting point of this compound was found to be $167-168^{\circ} \mathrm{C}$. $R_{f}$ value was found 0.48 in ethyl acetate: benzene (1:19). The molecular formula $\mathrm{C}_{29} \mathrm{H}_{48} \mathrm{O}$ deduced from its $\mathrm{GC}-\mathrm{MS}$ having mass 412.4 .

${ }^{1} \mathrm{H} \mathrm{NMR}\left(\delta, \mathrm{CDCl}_{3}\right) 0.74\left(\mathrm{~s}, 6 \mathrm{H}, 1 \times \mathrm{C}_{29}-\mathrm{CH}_{3}\right.$ and $\left.\mathrm{C}_{26}-\mathrm{CH}_{3}\right), 0.97\left(\mathrm{~s}, 6 \mathrm{H}, 1 \times \mathrm{C}_{24}-\mathrm{CH}_{3}\right.$ and $1 \times \mathrm{C}_{27}-$ $\left.\mathrm{CH}_{3}\right), 1.17\left(\mathrm{~s}, 3 \mathrm{H}, 1 \times \mathrm{C}_{28}-\mathrm{CH}_{3}\right), 1.21\left(\mathrm{~s}, 3 \mathrm{H}, 1 \times \mathrm{C}_{19}-\right.$ $\mathrm{CH}_{3}$ ), $3.78\left(\mathrm{~d}, \mathrm{~J}=4.0 \mathrm{~Hz}, 1 \mathrm{H}, 1 \times \mathrm{C}_{3}-\mathrm{CH}\right), 4.38(\mathrm{~s}, 1 \mathrm{H}$, $\left.1 \times \mathrm{C}_{23}-\mathrm{CH}\right), 4.86\left(\mathrm{~m}, \mathrm{~J}=16.0 \mathrm{~Hz}, 1 \mathrm{H}, 1 \times \mathrm{C}_{22}-\mathrm{CH}\right), 5.03$ (m, J=4.0Hz, $\left.1 \mathrm{H}, 1 \times \mathrm{C}_{6}-\mathrm{CH}\right), 7.28(\mathrm{~s}, 1 \mathrm{H}, 1 \times-\mathrm{OH})$.

IR

$v_{\mathrm{KBr}}^{\max }\left(\mathrm{cm}^{-1}\right) ; 3419,3322,2955,1462$, 1368, 1055, 801, 759,667.

GC-MS (m/z, relative abundance) 412.4(60), 351.3(25), 300.2(38), 255.2(77), 213.2(57), 159.2(100), 83.1(95).

Compound III was obtained as colorless crystals $(45 \mathrm{mg})$ on elution with benzene: hexane (1:9). It was recyrstallised from ethanol. Its melting 
point was found to be $145-147^{\circ} \mathrm{C}$. The molecular formula $\mathrm{C}_{29} \mathrm{H}_{50} \mathrm{O}$ was deduced from its GC-MS analysis.

${ }^{1} \mathrm{H} \operatorname{NMR}\left(\delta, \mathrm{CDCl}_{3}\right) 0.68(\mathrm{~s}, \mathrm{~J}=8.0 \mathrm{~Hz}, 3 \mathrm{H}$, $\left.1 \times \mathrm{C}_{18}-\mathrm{CH}_{3}\right), 0.79\left(\mathrm{~d}, \mathrm{~J}=4.0 \mathrm{~Hz}, 6 \mathrm{H}, 1 \times \mathrm{C}_{26}-\mathrm{CH}_{3}\right.$ and $\left.1 \times \mathrm{C}_{27}-\mathrm{CH}_{3}\right), 0.83\left(\mathrm{t}, \mathrm{J}=8.0 \mathrm{~Hz}, 3 \mathrm{H}, 1 \times \mathrm{C}_{21}-\mathrm{CH}_{3}\right)$, $0.90\left(\mathrm{~d}, \mathrm{~J}=4.0 \mathrm{~Hz}, 3 \mathrm{H}, 1 \times \mathrm{C}_{29}-\mathrm{CH}_{3}\right), 1.24(\mathrm{~s}, 3 \mathrm{H}$, $\left.1 \times \mathrm{C}_{19}-\mathrm{CH}_{3}\right), 5.12(\mathrm{~m}, 1 \mathrm{H},-\mathrm{OH}), 5.32(\mathrm{br}, \mathrm{J}=4.0 \mathrm{~Hz}$, $\left.1 \mathrm{H}, \mathrm{C}_{6}-\mathrm{CH}\right)$.

IR

$v_{\mathrm{KBr}}^{\max }\left(\mathrm{cm}^{-1}\right) ; 3419,2955,2852,1659$, 1462, 1378, 1055, 801, 759.

GC-MS (m/z, relative intensity) 414.4(80), 329.3(68), 303(41), 329.3(67), 255.2(65), 213.2(98), 145.1(100), 107.1(85).

Compound IV was isolated on elution with benzene: hexane (1:1) and crystallized out from benzene to get creamish salt like granules, $30 \mathrm{mg}$, melting point $70-74^{\circ} \mathrm{C}$. The compound IV responded to brown color in Libermann-Burchard's reaction. Its $R_{f}$ value was found to be 0.11 in benzene. The molecular formula $\mathrm{C}_{23} \mathrm{H}_{46} \mathrm{O}_{2}$ was deduced from $\mathrm{m} / \mathrm{z}$ 355 by it GC-MS.

${ }^{1} \mathrm{H} \operatorname{NMR}\left(\delta, \mathrm{CDCl}_{3}\right) 0.88(\mathrm{t}, \mathrm{J}=8.0 \mathrm{~Hz}, 3 \mathrm{H}$, $\left.1 \times-\mathrm{CH}_{3}\right), 1.26\left(\mathrm{br}, \mathrm{J}=4.0 \mathrm{~Hz}, 38 \mathrm{H}, 19 \times-\mathrm{CH}_{2}\right), 1.63$ $\left(\mathrm{m}, \mathrm{J}=8.0 \mathrm{~Hz}, 2 \mathrm{H}, 1 \times-\mathrm{CH}_{2}-\mathrm{CH}_{2} \mathrm{COOH}\right), 2.34(\mathrm{t}, \mathrm{J}=8.0$ $\left.\mathrm{Hz}, 2 \mathrm{H}, 1 \times-\mathrm{CH}_{2} \mathrm{COOH}\right)$.

\section{IR}

$v_{\mathrm{KBr}}^{\max }\left(\mathrm{cm}^{-1}\right) ; 2917,2849,1706,1471,1463,1432$, 1297, 1116, 939, 719.

GC-MS (m/z, relative intensity) 355.2 (5), 267.1 (10), 149.1 (6), 84(100).

\section{Biovaluation}

Test organism The antifungal activity of different extracts/fractions of stem of Moringa oleifera was investigated using two phytopathogenic fungi i.e. Rhizoctonia solani and Fusarium oxysporum which were obtained from the Department of Plant Pathology, College of Agriculture, Chaudhary Charan Singh Haryana Agricultural University, Hisar, Haryana, India. The fungal isolates were allowed to grow on Potato Dextrose Agar ${ }^{8}$ (PDA) at $25 \pm 2{ }^{\circ} \mathrm{C}$ until they sporulated. A 4-6 day old culture of each fungus was used for testing antifungal activity.

\section{Bioassay}

Poisoned Food Technique ${ }^{9}$ was used for determination of antifungal activity of different solvent fractions and extract of Moringa oleifera stem. Two sets were maintained- one for the treatment and another for control. The treatment set at different concentrations viz 250, 500, 1000 and $2000 \mu \mathrm{g} /$ $\mathrm{ml}$ was prepared by mixing the required quantity (25, 50, 100 and $200 \mathrm{mg}$ respectively) in $1 \mathrm{ml}$ of DMSO and then added pre-sterilized PDA. In control set, $1 \mathrm{ml}$ DMSO was mixed with PDA. These treatments and control were then poured in pre-sterilized Petri plates and allowed to solidify at room temperature. After solidification, mycelia disc of $5 \mathrm{~mm}$ diameter cut out from 4-6 day old culture of test fungi were aseptically placed in Petri plates of different treatment and control sets. The Petri plates were then wrapped with para film along the rim to prevent contamination. The inoculated plates were then inverted and incubated at $25 \pm 2{ }^{\circ} \mathrm{C}$ and the observations were recorded when the control plate got completely filled with test fungus. Colony diameter was determined by measuring the average radial growth of each plate. The data recorded in each case was mean of three replicates. The fungal growth inhibition (\%) was calculated by using the following formula.

$\%$ inhibition $=\frac{\mathrm{C}-\mathrm{T}}{\mathrm{C}} \times 100$

Where $\mathrm{C}=$ mycelia growth in control plate, $\mathrm{T}=$ mycelia growth in treated plate

The concentration of plant extract/ fractions producing $50 \%$ growth inhibition $\left(E_{50}\right)$ was calculated using SPSS Statistics 19 software.

\section{Data Analysis}

All the experimental measurements were carried out in triplicate and results were presented as mean \pm standard deviation. One way and two way analysis of variance (ANOVA) was carried out to assess any significant differences between the means $(p<0.05)$ in Online Statistical Analysis (OPSTAT), CCS HAU, Hisar. EC Fo $_{50}$ values of antifungal activity were calculated using SPSS Statistics 19 software. All other measurements and calculations were carried out in Microsoft Excel 2007. 


\section{RESULTS AND DISCUSSION}

\section{Preliminary phytochemical screening}

Methanolic extract of stem of $M$. oleifera was screened for various phytochemicals like saponins, tannins, phytosterols, terpenoids, flavonoids, etc. The major phytochemicals found present were saponins, carbohydrates, anthraquinone glycosides, alkaloids, flavonoids, terpenoids, phytosterols, proteins and amino acids which are shown by positive (+ive) sign in table1 while tannins and cardiac glycosides were found to be absent and shown by negative sign (-ive).

\section{Isolation and characterization of isolated compounds \\ Compound I, (Cholest-5-en-3-ol)}

Compound I was obtained on elution with benzene: hexane (1:9). Its Rf value was found to be 0.42 in benzene. Its melting point was found to be $144-146{ }^{\circ} \mathrm{C}$ which is in agreement with the literature data $148-150{ }^{\circ} \mathrm{C}^{10}$. GC-MS analysis of compound I showed that its molecular mass is 400 with molecular formula $\mathrm{C}_{28} \mathrm{H}_{48} \mathrm{O}$. The IR spectra of the compound showed that it does not possess a carbonyl group which is confirmed by absence of absorption bands ranging from $1725-1810 \mathrm{~cm}^{-1}$. The absorptions ranging from $660-1100 \mathrm{~cm}^{-1}$ are characteristic absorptions of steroids. The absorption bands at 3419 and $3322 \mathrm{~cm}^{-1}$ indicated the presence of hydroxyl group.
The ${ }^{1} \mathrm{H}$ NMR of compound I in $\mathrm{CDCl}_{3}$ exhibited a multiplet at $5.34 \delta$ attributed to coupling of the $\mathrm{H}$-atom which is bonded to $\mathrm{sp}^{2}$ carbon atom $(\mathrm{H}-6)$ with hydrogen atoms on adjacent $\mathrm{CH}_{2}$ group. A multiplet at $3.60 \delta$ was assignable to a proton $(\mathrm{H}-3)$ bonded to $-\mathrm{OH}$ group. Six singlets of methyl functionality integrating for three protons each appeared at 0.88, 0.90, 0.97, 1.11, 1.15 and $1.18 \delta$. Another multiplet observed ranging from 1.24-2.88 corresponds to the remaining ten methylene and six methine protons in cholest-5en-3-ol. All the above spectral data is in agreement for the following structure which corresponds to cholest-5-en-3-ol. This is the first report of isolation and characterization of cholest-5-en-3-ol from stem of Moringa oleifera.

\section{Compound II, (Stigmasterol)}

Compound II was obtained on elution with benzene: hexane (1:9). Its $R_{f}$ value was found to be 0.48 in ethyl acetate: benzene (1:19). Its melting point was found to be $167-168^{\circ} \mathrm{C}$ (literature m.p. $\left.169.5^{\circ} \mathrm{C}^{11}\right)$. The absorptions at 3419 and $3322 \mathrm{~cm}^{-1}$ in its IR spectra confirmed the presence of $-\mathrm{OH}$ functionality in its structure. The molecular formula $\mathrm{C}_{29} \mathrm{H}_{48} \mathrm{O}$ was deduced from its GC-MS with molecular mass 412.4 .

In ${ }^{1} \mathrm{H}$ NMR spectra of the compound in $\mathrm{CDCl}_{3}$, a singlet at $0.74 \delta$ indicated the presence of six protons of two methyl groups. Six protons of

Table 1: Preliminary phytochemical screening of methanolic extract of stem of Moringa oleifera

\begin{tabular}{cccr}
\hline Sr. no. & Phytochemicals tested & Name of the test & Result \\
\hline 1. & Saponins & Frothing test & + ive \\
2. & Tannins & Ferric chloride test & -ive \\
3. & Carbohydrates & Fehling's test, Tollen's reagent test & + +ive \\
4. & Cardiac glycosides & Keller-Killiani test & -ive \\
5. & Anthraquinone glycosides & Hydroxyanthraquinine test & + ive \\
6. & Alkaloids & Hager's test & + ive \\
7. & Flavonoids & Alkaline reagent test & + ive \\
8. & Terpenoids & Salkowski test & + ive \\
9. & Phytosterols & Liebermann- Burchard's test & + ive \\
10. & Protein & Biuret test & + ive \\
11. & Amino acids & Millon's test & + ive \\
\hline
\end{tabular}

+ive shows the presence while -ive shows the absence. 
another two methyl groups could be picked up at $0.97 \delta$ as a singlet. Two singlets appeared at $1.17 \delta$ and $1.21 \delta$ for two methyl groups positioned at $\mathrm{C}_{19}$ and $\mathrm{C}_{28}$. A doublet at $3.78 \delta$ with coupling constant $(\mathrm{J}=4.0 \mathrm{~Hz})$ integrating for one proton assignable to $-\mathrm{CH}$ moiety attached to $-\mathrm{OH}$ group at $\mathrm{C}_{3}$ position. A singlet centred at $4.38 \delta$ for one proton was assignable to hydrogen at $\mathrm{C}_{23}$. ${ }^{1} \mathrm{HNMR}$ spectra displayed a multiplet at 4.868 integrating for one proton at $\mathrm{C}_{22}$. A singlet at 7.288 integrating for one proton confirmed the presence of hydroxyl group in it. The spectroscopic data was in agreement with the literature data12 of stigmasterol. This is the first report of isolation and characterization of this compound from Moringa oleifera stem.

\section{Compound III, (Gamma-sitosterol)}

Compound III was obtained on elution with benzene: hexane (1:9) and crystallised out from ethanol, $45 \mathrm{mg}$, melting point $145-147{ }^{\circ} \mathrm{C}$ (literature m.p. 147-148 ${ }^{\circ} \mathrm{C}^{13}$ ). It gave green color in Liebermann-Burchard reaction indicating the presence of steroids. GC-MS analysis of this compound suggested the molecular formula to be $\mathrm{C}_{29} \mathrm{H}_{50} \mathrm{O}$ and molecular mass 414 . Its IR spectra gave absorption peak at $3419 \mathrm{~cm}^{-1}$ indicating the presence of hydroxyl group in the compound. Other absorption peaks at 2955, 2852, 1659, 1462, 1378, 1055, 801 and $759 \mathrm{~cm}^{-1}$.

The ${ }^{1} \mathrm{H}$ NMR spectra of the compound III in $\mathrm{CDCl}_{3}$ exhibited a singlet at $0.68 \delta$ for three protons which was assignable to methyl group present at $C_{18}$ position. A doublet centered at $0.79 \delta$ with $\mathrm{J}=4.0 \mathrm{~Hz}$ integrating for six protons indicated two methyl groups positioned at $\mathrm{C}_{26}$ and $\mathrm{C}_{27}$. A doublet centered at $0.90 \delta$ with $\mathrm{J}=4.0 \mathrm{~Hz}$ integrating three protons suggested the presence of a methyl group at $\mathrm{C}_{21}$ and a triplet at $0.83 \delta(\mathrm{J}=8.0 \mathrm{~Hz})$ representing three protons was assignable to methyl group at $\mathrm{C}_{29}$ position. A singlet at $1.24 \delta$ representing three protons could be due to methyl group at $\mathrm{C}_{19}$ position. A multiplet centered at $5.12 \delta$ integrating for one proton could be of hydroxyl group. A broad signal at $5.32 \delta$ for one proton was assigned to an olefinic proton. The spectral analysis is in perfect agreement with the literature data of $\delta$-sitosterol. From the literature survey, it seems that this is the first time report of gamma-sitosterol from stem of Moringa oleifera.

\section{Compound IV, (Tricosanoic acid)}

Methanolic extract of stem of Moringa oleifera when subjected to column chromatography gave compound IV with benzene: hexane (1:1) solvent system. Total twenty nine fractions were collected and monitored by TLC. It was crystallised in benzene $(30 \mathrm{mg})$ and having melting point $70-74$ ${ }^{\circ} \mathrm{C}$. Its molecular formula, $\mathrm{C}_{23} \mathrm{H}_{46} \mathrm{O}_{2}$ was deduced from GC-MS with molecular mass 355. Absorptions at $1706 \mathrm{~cm}^{-1}$ in IR spectra confirmed the presence of $>\mathrm{C}=\mathrm{O}$ group in this compound. Other absorptions appeared at 2917, 2849, 1463, 1116 and $719 \mathrm{~cm}^{-1}$.

The ${ }^{1}$ HNMR spectra of this compound showed a single peak at 7.268 which represents the residual peak of $\mathrm{CDCl}_{3}$. The spectrum exhibited a triplet at $2.34 \delta$ for two hydrogens with $\mathrm{J}$ value 8.0 $\mathrm{Hz}$ adjacent to carboxylic acid group. A multiplet was observed at $1.63 \delta$ for methylene protons at $\mathrm{C}_{-3}$ position. A broad singlet appeared at $1.26 \delta$ for another methylene integrating for thirty eight protons. A sharp triplet at $0.88 \delta$ appeared for terminal methyl protons. The spectral data helped us to identify the compound IV to be tricosanoic acid. This is the first report of isolation and characterization of tricosanoic acid from stem of Moringa oleifera.

\section{Bioevaluation}

\section{Antifungal activity of stem of Moringa oleifera}

Antifungal activity of different extract/ fractions of stem of $M$. oleifera against Rhizoctonia solani and Fusarium oxysporum are presented in Fig. 3 and 4. A perusal of the data showed that irrespective of the concentration, $2000 \mu \mathrm{g} / \mathrm{ml}$ concentration was found to be the most toxic and $250 \mu \mathrm{g} / \mathrm{ml}$ concentration was the least toxic. All the extract/ fractions of stem of drumstick tree were found to be more active against $R$. solani than F. oxysporum. Methanol extract was found to be the most active at $2000 \mu \mathrm{g} / \mathrm{ml}$ concentration with $68.43 \pm 1.48 \%$ growth inhibition against $R$. solani while in terms of $\mathrm{EC}_{50}$ value ethyl acetate fraction was found to be the most active with $804.14 \mu \mathrm{g} / \mathrm{ml} \mathrm{EC}_{50}$ value. Against $F$. oxysporum, the maximum activity 
was shown by chloroform fraction at $2000 \mu \mathrm{g} / \mathrm{ml}$ concentration with $59.22 \pm 0.34 \%$ growth inhibition and $1457.17 \mu \mathrm{g} / \mathrm{ml} \mathrm{EC}_{50}$ value. Minimum activity was shown by water fraction of stem of $M$. oleifera at $250 \mu \mathrm{g} / \mathrm{ml}$ concentration against $R$. solani and $F$. oxysporum. Moderate activity was shown by hexane, benzene, chloroform and ethyl acetate fractions against $R$. solani. While against F. oxysporum, moderate activity was shown by benzene, ethyl

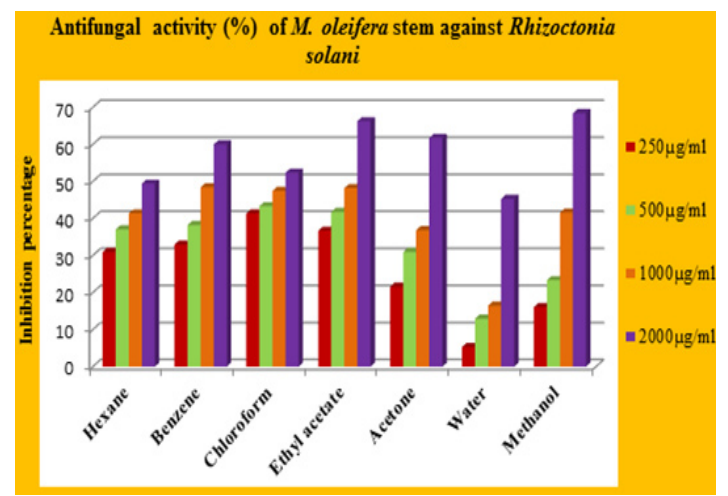

Fig. 3. Antifungal activity of various extract/ fractions of stem of Moringa oleifera against Rhizoctonia solani acetate and water fractions. A significant difference was found among all the fractions at different test concentrations. Critical difference values for antifungal activity of various extract/ fractions of stem of Moringa oleifera were calculated. Interaction of compounds and concentrations was statistically significant with a value 1.868 against $R$. solani and 1.011 against $F$. oxysporum for concentration $x$ compound.

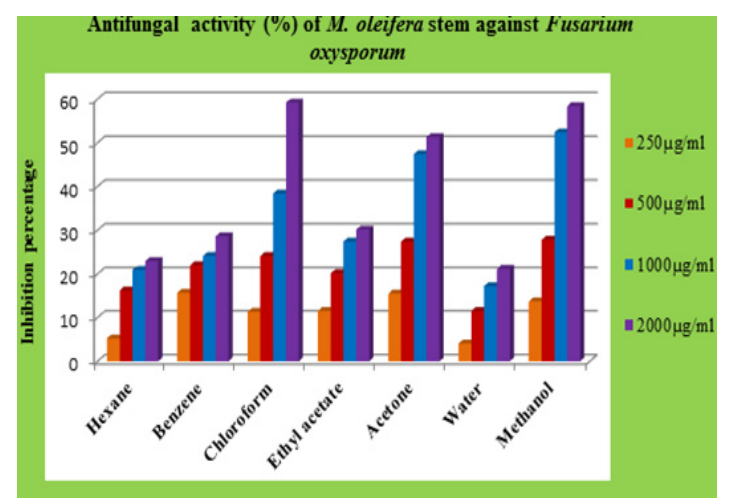

Fig. 4. Antifungal activity of various extract/ fractions of stem of Moringa oleifera against Fusarium

Table 2: Antifungal activity (\%) and $\mathrm{EC}_{50}$ values $(\mu \mathrm{g} / \mathrm{ml})$ of various extract/ fractions of stem of Moringa oleifera against Rhizoctonia solani

\begin{tabular}{|c|c|c|c|c|c|c|}
\hline \multirow[t]{2}{*}{ Sr. No. } & \multirow[t]{2}{*}{ Extract/ Fractions } & \multicolumn{4}{|c|}{ Percentage Growth Inhibition } & \multirow[t]{2}{*}{$\mathrm{EC}_{50}(\mu \mathrm{g} / \mathrm{ml})$} \\
\hline & & $250 \mu \mathrm{g} / \mathrm{ml}$ & $500 \mu \mathrm{g} / \mathrm{ml}$ & $1000 \mu \mathrm{g} / \mathrm{ml}$ & $2000 \mu \mathrm{g} / \mathrm{ml}$ & \\
\hline 1. & Hexane & $30.98 \pm 1.80$ & $37.06 \pm 0.59$ & $41.37 \pm 0.34$ & $49.41 \pm 1.18$ & 2295.65 \\
\hline 2. & Benzene & $32.94 \pm 0.00$ & $38.24 \pm 0.59$ & $48.43 \pm 0.34$ & $60.00 \pm 1.02$ & 1044.47 \\
\hline 3. & Chloroform & $41.37 \pm 0.34$ & $43.33 \pm 0.68$ & $47.45 \pm 2.07$ & $52.35 \pm 2.12$ & 1500.32 \\
\hline 4. & Ethyl acetate & $36.67 \pm 1.48$ & $41.76 \pm 0.59$ & $48.24 \pm 0.59$ & $66.27 \pm 0.34$ & 804.14 \\
\hline 5. & Acetone & $21.57 \pm 1.48$ & $30.98 \pm 0.90$ & $36.86 \pm 0.34$ & $61.76 \pm 0.59$ & 1378.48 \\
\hline 6. & Water & $5.29 \pm 0.59$ & $12.94 \pm 0.59$ & $16.47 \pm 0.59$ & $45.29 \pm 1.18$ & 1378.48 \\
\hline \multirow[t]{5}{*}{7.} & Methanol & $16.08 \pm 2.38$ & $23.33 \pm 1.89$ & $41.57 \pm 0.34$ & $68.43 \pm 1.48$ & 1178.82 \\
\hline & Factors & & SE(d) & & CD at $5 \%$ & \\
\hline & Concentration & & 0.352 & & 0.706 & \\
\hline & Compound & & 0.465 & & 0.934 & \\
\hline & Conc. $\times$ Compound & & 0.930 & & 1.868 & \\
\hline
\end{tabular}

All the values are mean \pm S.D.

Mean of three replicates was taken $(n=3)$.

$\mu \mathrm{g} / \mathrm{ml}$ means microgram per millilitre.

$\mathrm{EC}_{50}$ means inhibition concentration at which $50 \%$ of the growth is inhibited 
Table 3: Antifungal activity $(\%)$ and $\mathrm{EC}_{50}$ values $(\mu \mathrm{g} / \mathrm{ml})$ of various extract/ fractions of stem of Moringa oleifera against Fusarium oxysporum

\begin{tabular}{|c|c|c|c|c|c|c|}
\hline \multirow[t]{2}{*}{ Sr. No. } & \multirow[t]{2}{*}{ Extract/ Fractions } & \multicolumn{3}{|c|}{ Percentage Growth Inhibition } & \multicolumn{2}{|r|}{$\mathrm{EC}_{50}(\mu \mathrm{g} / \mathrm{ml})$} \\
\hline & & $250 \mu \mathrm{g} / \mathrm{ml}$ & $500 \mu \mathrm{g} / \mathrm{ml}$ & $1000 \mu \mathrm{g} / \mathrm{ml}$ & $2000 \mu \mathrm{g} / \mathrm{ml}$ & \\
\hline 1. & Hexane & $5.29 \pm 0.59$ & $16.27 \pm 0.34$ & $20.98 \pm 0.34$ & $22.94 \pm 1.02$ & 4129.82 \\
\hline 2. & Benzene & $15.69 \pm 1.36$ & $21.96 \pm 0.34$ & $24.12 \pm 0.59$ & $28.63 \pm 0.34$ & 4664.56 \\
\hline 3. & Chloroform & $11.37 \pm 0.34$ & $24.12 \pm 0.59$ & $38.43 \pm 0.34$ & $59.22 \pm 0.34$ & 1457.17 \\
\hline 4. & Ethyl acetate & $11.57 \pm 0.34$ & $20.20 \pm 0.90$ & $27.45 \pm 0.68$ & $30.20 \pm 0.68$ & 3790.44 \\
\hline 5. & Acetone & $15.49 \pm 0.34$ & $27.45 \pm 0.68$ & $47.45 \pm 0.34$ & $51.37 \pm 0.68$ & 1537.03 \\
\hline 6. & Water & $4.12 \pm 0.59$ & $11.57 \pm 0.34$ & $17.25 \pm 0.68$ & $21.18 \pm 1.18$ & 4740.79 \\
\hline \multirow[t]{5}{*}{7.} & Methanol & $13.73 \pm 0.68$ & $27.84 \pm 0.34$ & $52.41 \pm 0.50$ & $58.43 \pm 0.34$ & 1196.90 \\
\hline & Factors & $\mathrm{SE}(\mathrm{d})$ & CD at $5 \%$ & & & \\
\hline & Concentration & 0.190 & 0.382 & & & \\
\hline & Compound & 0.252 & 0.505 & & & \\
\hline & Conc. $\times$ Compound & 0.503 & 1.011 & & & \\
\hline
\end{tabular}

All the values are mean \pm S.D.

Mean of three replicates was taken $(n=3)$.

$\mu \mathrm{g} / \mathrm{ml}$ means microgram per millilitre.

$\mathrm{EC}_{50}$ means inhibition concentration at which $50 \%$ of the growth is inhibited.

\section{ACKNOWLEDGEMENT}

Authors are thankful to SAIF, CIL and UCIL, Panjab University, Chandigarh for providing facilities for spectral analysis. We are also grateful to Department of Chemistry and Biochemistry and Department of Plant Pathology, CCS HAU, Hisar.

\section{REFERENCES}

1. Mughal, M. H.; Ali, G.; Srivasta, P. S.; Iqbal, M. Harmdad Med., 1999, 42, 37-42.

2. Khare, C. P. Encyclopedia of Indian Medicinal Plants, Springer, Berlin, 2004.

3. Kirtikar, K. R.; Basu, B. D. Indian Medicinal Plants., 1975, 1(2), 676-683.

4. Anwar, F.; Latif, S.; Ashraf, M.; Gilani, A. H. Phytother. Res., 2007, 21(1), 17-25.

5. Fuglie, L. J. The Moringa Tree: A Local Solution to Malnutrition. Published in Dakar, Senegal., 2005.

6. Dhakar, R. C.; Maurya, S. D.; Pooniya, B. K.; Bairwa, N.; Gupta, M. Chron. Young Sci., 2011, 2(3), 119.

7. Sánchez-Machado, D. I.; Núñez-Gastélum, J. A.; Reyes-Moreno, C.; Ramírez-Wong, B.;
López-Cervantes, J. Food Anal. Methods. 2010, 3(3), 175-180.

8. Tuite, J. Plant pathological methods, fungi and bacteria. Burgess Publishing Co., Minneapolis, Minn., 1969.

9. Grover, R. K.; Moore, J. D. Phytopathology, 1962, 52, 876-880.

10. Williams, J. H.; Kuchmak, M.; Witter, R. F. J.Lipid Res., 1965, 6(4), 461-465.

11. Buckingham, J. Dictionary of Natural Products Supplement, CRC., 1997, 4(11).

12. Rajput, A. P.; Rajput, T. Int. J. Biochem. Chem., 2012, 6, 130-135.

13. Balamurugan, R.; Stalin, A.; Ignacimuthu, S. Eur. J. Med. Chem., 2012, 47, 38-43. 